\title{
Dividing to conquer: Employing the separation of powers to structure institutional inter-relations
}

\author{
Hugh Breakey
}

\begin{abstract}
The separation of powers constitutes a vital feature of western democracies, enshrined in myriad federal and state constitutions. Yet, as a broad principle, theorists struggle to pin down its precise nature, and many contend that the tripartite separation of state powers into legislative, executive and judicial branches proves simplistic and infeasible. I argue we should understand the separation of powers as a strategy used to structure relations between the separated institutions. This process of structuring empowers the creation of novel inter-relations among institutions (relations of balancing, checking, dividing, coordinating and so on), with the goal of improving their institutional integrity. In short, we separate only to reconnect.
\end{abstract}

Keywords: Separation of powers; Locke, John; Montesquieu; governance; institutional integrity; checks and balances; balance of powers. 


\section{Introduction}

The separation of powers constitutes an important structural feature of western democracies, enshrined in many federal and state constitutions. Yet, as a broad principle, theorists struggle to pin down its precise nature. Many commentators object that the tripartite separation of state powers into legislative, executive and judiciary-sometimes traced to Montesquieu's (1748/1989) The Spirit of the Laws - is overly simplistic. No state observes a strict separation of powers along these divisions, and it is difficult to see how such a separation could be feasible, much less desirable.

Indeed, some critics see the separation of powers as riven by paradox. On one hand, the doctrine enjoins the separation of state institutions on the basis of their specific functions; on the other, it is connected to the idea of checks and balances. But to have one institution checking the power of another effectively scrambles the very divisions created by the initial separation (L. Little, 2000, pp. 54-55; Singer, 2009, p. 110). To allow the executive to veto legislation, or to allow the judiciary to strike down legislation through judicial review, for example, might be lauded as a healthy check on the dominance of the legislature that is made possible through the separation of powers. Alternatively, such mechanisms might be castigated as violations of the separation of powers, because they allow nonlegislative powers to interfere with the legislature's business of creating new law. Awareness of these perplexing aspects of the separation of powers doctrine dates back at least to Madison in the late eighteenth century (Hamiliton, Madison, \& Jay, 1778/2008, pp. 240-244). As a result of these tensions, some critics reject the significance of the separation of powers, seeing its invocation as little more than a baseless dogma (Carolan, 2009; Magill, 2000). 
The critics have a point. Certainly, some of the benefits ascribed to the doctrine are under-explored, if not inscrutable. For example, in his analysis of the Lockean separation of powers, Zuckert $(2012$, p. 361) suggests that one reason for keeping the executive branch separate from the legislative is that, with the power to enforce (and hence also to not enforce) the laws, such an executive might exempt itself from the laws of the land. Doubtless this is a real concern-but it is puzzling how the separation of powers solves it. An executive that disobeys laws remains a threat to the rule of law even if it enjoys no powers of legislation. A similar qualm arises with respect to one of Montesquieu's most oft-quoted remarks: 'When legislative power is united with executive power in a single person or in a single body of magistrates, there is no liberty, because one can fear that the same monarch or senate that makes tyrannical laws will execute them tyrannically' (1748/1989, p. 157). Again, it is hard to grasp Montesquieu's point here. Do we have any reason to believe that two institutions acting severally will be any less tyrannical than one institution acting alone? If it is sensible to distrust one institution acting alone, why is there not the same distrust (twice the distrust!) for two institutions, each potentially abusing their power as they vote and veto?

Although they ask fundamental questions of the doctrine, the critics do not turn to the foundational works by Locke, Montesquieu and Kant for answers. In this article I take up the sceptics' challenge, and return to these seminal works to explain how the separation of powers promotes institutional integrity. The answer I provide is not a simple one. I argue that we should think of the separation of powers as a rubric-a wide category that includes many complex governance strategies. These strategies direct our attention to the interrelations between various institutions-inter-relations that can be structured to improve 
the integrity of each institution. 'Integrity' here refers to the capacity of the institution to achieve its publically stated purpose or mission (Wueste, 2005, p. 9). In recent literature on integrity systems and transparency, focus has shifted from concern with the existence of discrete anticorruption institutions to the question of the inter-relations between institutions (Sampford, Smith, \& Brown, 2005). This shift accords with the insights of political theorists such as Locke, Montesquieu and Kant. These theorists perceived that whether an institution will fulfil its task effectively, and stay within the limits of its authority as it does so, is fundamentally a function of its relationship to other institutions.

I argue for this thesis by showing the variety of different institutional arrangements falling under the larger separation of powers rubric, and I flesh out the reasons advanced for these arrangements. Far from the separation of powers being a single, simple doctrine, the rubric encompasses an array of inter-relationships that improve the integrity of institutions, and limit their intrusiveness and ambitions. The constitutional structures of western polities established many of these relationships. But these relationships are worth understanding so they can also be fostered in other situations. Whenever we are trying to improve the integrity of a given institution, the following argument implies that we should ask questions such as:

What is the relationship of this institution to other relevant institutions?

Will other institutions oppose its functioning, and could this be a socially useful opposition?

Should the personnel of this institution overlap with other institutions? 
Should this institution be divided into constituent parts, with each part checking on the others?

These are the types of questions that insights into the separation of powers encourage us to ask, and help us to answer.

Before proceeding, one definitional matter: The word 'powers' in 'separation of powers' is ambiguous, having at least four separate meanings (Vile, 1998, pp. 13-14). A first meaning of a 'power' is a body, branch or institution. A second meaning is a type of function or task, that is, a role an institution performs, such as 'lawmaking' or 'border protection'. A third meaning concerns the capacities, methods or authority needed by the institution to carry out its task. When a person claims that an act is ultra vires ('beyond power') they connote these second and third meanings. An act ultra vires is one that is outside the mandated role of the body (its function), or outside the scope of action delegated to that body (its authorized capacities). A fourth and final meaning is the overall strength to actthe sheer power and resources an institution possesses to survive, expand, resist, compel, resource, reward, disrupt, threaten and influence. Strength can be greater or smaller than the capacity and authority officially granted to the institution. Thus, one institution may be too weak to adequately perform its mandated task, whereas another may have capabilities stretching well beyond its official ambit. To avoid confusion, I refer to: 'body' or 'institution'; 'function' or 'task'; 'capacity' or 'authority'; and 'strength'. Whenever I speak of the 'separation of powers doctrine', I refer to the compound thesis that, (a) different institutions peopled by different personnel, (b) should perform the separate tasks of government, there being, (c) three such tasks: rule making, rule judging, and rule enforcing (severally, legislating, judging and executing). 


\section{The separation of institutional processes}

One straightforward meaning of the separation of powers is the creation of specific institutions for specific tasks. This need not require the institution to have no overlap in personnel with other institutions, or no connections with those institutions. This strategy simply says that if one needs four (say) distinct tasks to be fulfilled, it might be advisable to establish four distinct institutions, systems or processes to perform those tasks. Why does this separation of institutions improve integrity? There are three reasons, each of which is expanded on below: it is efficient for separate processes to perform distinct tasks; separate institutional processes can constrain discretionary authority; and separate institutional processes prevent the compromising of specific tasks.

\section{It is efficient for separate processes to perform distinct tasks?}

John Locke (1690/1947) was one of the first major political theorists to argue for a separation of powers. Locke's life-long project was to limit political authority (Ward, 2005; Zuckert, 2012). In his Second Treatise of Government, Locke argued against absolute sovereignty, taking issue with previous seventeenth century political theorists who had argued for a supreme sovereign. Thomas Hobbes, for example, charged that only a supreme sovereign could rescue humanity from the 'state of nature', which Hobbes conceived as a lawless war of all against all.

Locke agreed it was helpful to think about political authority by beginning with the pre-political state of nature. He disagreed, however, with Hobbes' characterization of that state. Locke argued that natural law bound people even within the state of nature. Societies, and even economies, were therefore possible. Even so, Locke acknowledged, the 
state of nature was plagued with serious deficiencies. Although there was a general moral law of nature, there was: no standing, agreed, publicly known law; no-one tasked with impartially enforcing the law, and; no accepted, impartial judge of breaches of law and appropriate punishments (Locke, 1690/1947, II:124-126). To remedy these deficiencies, Locke argued, people consented to the creation of a political community. But this did not mean they consented to a ruler with sweeping powers and wide prerogatives. Rather, the people needed three discrete tasks to be performed, and would therefore consent to the creation of institutions performing each of those tasks-namely, the legislature, the executive and the judiciary.

In order to fulfil their roles, each institution needs to have a particular structure and be populated with personnel with particular expertise. The legislation needs to be representative and a forum for discussion and debate, the executive to be empowered to act swiftly, and the judiciary to provide impartial and consistent judgments on the basis of standing law.

The different modes of decision-making employed by different institutions make them ideal for some purposes, but less apt for others. For example, judicial modes of inquiry tend to be conservative and victim focused. Although appropriate in the context of rule violations and criminal punishments, judicial processes struggle with issues (e.g. those concerning the environment) that require system-wide reform and the type of leadership only found in the executive or legislative realms (Brown, 1992, pp. 83-85). Equally, the sheer size of legislatures and the resulting diffusion of responsibility render such institutions inapt for executive and judicial actions impacting upon particular individuals and disputes (Vile, 1998, p. 54). Hence, institutions should be designed so as to facilitate their efficacy, and 
should possess the tools and expertise suitable for performing their tasks. This rather common-sense insight recommends separate institutions for the performance of different tasks. But Locke also had a deeper point in mind.

\section{Separate institutional processes can constrain authority}

In Locke's view, people create political authority by relinquishing their natural freedoms. Locke believed that people would only consent (and should only consent) to those limitations on their freedom that were absolutely necessary. Thus, it was crucial to be specific about the necessary tasks to be accomplished. After all, the population could have created a supreme sovereign handling all three functions. But by specifying each task, and then granting to each specific body only the authorities and resources needed to enable it to perform that task, the populace ensured it was giving up as few liberties as possible. Rather than a catch-all ruler with catch-all powers, the people would have, severally, a lawmaker, an enforcer and a judge. The specification of separate institutions to perform separate tasks thus contributed to the fundamental task of the Lockean constitution: 'being strong enough to act to serve rights and the public good without, at the same time, being a greater threat to these rights than continued life in the state of nature would be' (Zuckert, 2012, p. 360).

This arrangement of dedicated institutions also served to limit the discretion granted to the authorities. Each institution had discretion over specific decisions, granted to them for specific purposes. This narrower range of discretion made abuse more difficult because it constrained the choices available to the decision-makers. The strategy also made abuses easier to detect, because each type of authorized discretion was directed towards a specific 
purpose; thus, by specifying institutions, delegated discretionary authority could be kept to a minimum.

\section{Separate institutional processes prevent the compromising of specific tasks}

Madison (1778/2008, p. 239) famously averred: 'The accumulation of all powers, legislative, executive, and judiciary, in the same hands, whether of one, a few, or many, and whether hereditary, self-appointed, or elective, may justly be pronounced the very definition of tyranny'. As critics have complained however, this claim cries out for defense (Magill, 2000, p. 1183). Why should tyranny be equated by definition with the failure to separate powers?

Immanuel Kant drew the same link, and his reasons can help us understand Madison's point. Kant argued an executive 'that was also legislative would have to be called a despotic as opposed to a patriotic government' $(1797 / 1996, \text { p. } 6: 317)^{1}$. Now if we picture an executive (e.g. a powerful monarch) as an institution designed to enforce laws, and then provide that institution with lawmaking capabilities, it is not hard to see how tyranny might emerge. For an institution to achieve democratic legitimacy it must possess space for lively debate, and be connected to the people's elected representatives. An executive does not possess these qualities, and thus cannot reflect what Kant, following Rousseau, called the 'general will'. Such considerations, however, do not mean that any breach in the separation

\footnotetext{
${ }^{1}$ Pogge (2009) believes Kant's 'absolutist' conception of sovereignty clashes with a vertical division of powers, and would therefore resist the tangled inter-relations of powers propounded here. However, Formosa argues that Pogge's position rests upon a mistaken conflation of powers (which may be divided) and the people's sovereignty as general will (which must remain supreme). Far from Kant's conception of sovereignty being in tension with a division of powers, Formosa argues that Kant's polity requires such a division (2014, pp. 41-42). The distinction Formosa draws is found throughout history; theorists (including Kant's major influence, Rousseau)-routinely spoke of an 'absolute' or 'supreme' power even as they separated institutions and introduced checks and balances (Vile, 1998, pp. 46, 69, 158-159, 195-199).
} 
of powers invites tyranny. Suppose instead we begin with a legislature that represents the people and is a forum for lively deliberation. Asking that institution to enforce the law might be inefficient, but it is not tyrannical. Yet separation-of-powers theorists have feared a democratic legislature holding executive power as much as they have feared the powers wielded by monarchs (Hamiliton, et al., 1778/2008, p. 246; Jefferson, 1993, p. 52; Vile, 1998, p. 51).

So what might these theorists have had in mind? Kant's discussion of the link between despotism and the separation of powers is brief, but it is possible to reconstruct some important strands of his thinking. Kant attends to two features of the executive (1797/1996, pp. 6:316-317), as did Locke earlier (1690/1947, II:136-142). First, the executive is empowered to give directives applying to individual cases and persons. Second, she can change such directives simply by her choice. Both these qualities threaten the rule of law, the first by departing from general rules that apply equally to all (because the executive can give targeted decrees), and the second by departing from prior, standing laws (because the executive can alter duties as she pleases). If the executive is working within a settled framework of prior constraints she does not control, the threat is constrained, and perhaps even dissolved. But if the executive can herself refigure those constraining rules at will, then the threat is grave indeed. The executive's capacity to impose personal, changing decrees sunders its connection to the rule of law. ${ }^{2}$ But this is precisely the situation created when a

\footnotetext{
${ }^{2}$ Magill accepts that the 'rule-of-law thesis' potentially justifies the separation of powers. She argues against it, however, on the basis that it is (she asserts) 'daunting if not impossible' to separate lawmaking from law implementation (1999; 1192). (Magill, as I read her, is not saying it is a challenge to attach the separation of powers to the rule of law; rather, she is denying the rule of law per se. If there is no distinction between rule making and rule implementation, then the rule of law must, by definition, be impossible.) It is true that there are boundary cases where a reasonable person might not be sure at what point legal implementation finishes
} 
legislature enjoys executive powers - and a polity without the rule of law is, by definition, a tyranny.

Another way of putting Kant's point brings to the fore the link to institutional integrity. A polity needs two tasks fulfilled to achieve the rule of law: the creation of general standing laws, and the enforcement of those laws. This latter task requires the imposition of specific and changeable commands. Thus, if two institutions are combined, such that the new institution can perform both tasks at the same time, then the new institution's capacity to impose targeted and alterable decrees alters the status of the general standing laws it creates. These laws are now subject to immediate, discretionary change and exception. Worse, these changes can be applied to particular cases, allowing the law to apply to some people, but not others. Moreover, these alterations have the same provenance and authority as the original laws. These features fracture the previous capacity of the legislative body's edicts to play their role in the rule of law. Ultimately, giving the institution a new task (execution) confounds its prior task (legislation). As Fuller (1955, p. 917) points out, we must first ask what purposes a social institution serves in society, 'and then reason out what restraints must be observed if those purposes are to be achieved'. In this case, in giving a single body the two tasks of legislation and execution, the discrete conditions required by the rule of law are no longer met.

and legal creation begins, but this appeal to marginal cases provides little reason to doubt the tenability of the distinction more generally. By way of analogy, the fact that there are boundary cases between baldness and hairiness where it is impossible to determine whether we should describe Alf's head as bald provides little reason to think there is no distinction between baldness and hairiness. Vagueness in marginal cases presents no reason for rejecting concepts themselves. 
Having executive and judicial capabilities exercised by a legislature is not a fanciful abstract concern, but an all-too-real historical situation that Enlightenment political theorists were trying to prevent. The Long Parliament in England in the mid-seventeenth century, 'governed the country by appointing a host of committees dealing with all the affairs of state, confiscating property, summoning people before them, and dealing with them in summary fashion' (Vile, 1998, p. 48). The National Convention governing France in 1792 behaved little better (Vile, 1998, p. 208).

\section{Section summation: Separation of powers requires distinct institutional processes}

The three advantages discussed above provide reasons for creating distinct institutions to fulfil distinct tasks. Securing these advantages need not mean that one person cannot have a role across all three institutions. We can imagine a figure who holds a leading role in all three institutions-a member of the sitting parliament and of the executive dealing with crises as they unfold, and at other times a judge in a court of law. Provided these were three distinct institutions, with different processes, and the individual assumed the role of each when required (e.g. putting on her legislative 'hat'), then these three benefits are all achievable. Indeed, this seems true even of Kant's rationale for the separation of powers based on the rule of law. Provided the legislative creation of general laws is separated from the executive's particularised decrees, the same person's involvement in both institutions need not vitiate the rule of law.

Of course, Locke and Kant thought there were reasons to avoid populating the different institutions with the same people. But we can still talk meaningfully about the advantages of the separation of powers where we connote only separate, dedicated institutions solving particular tasks, reserving any judgment about whether those 
institutions share personnel. The mere fact, then, that many modern polities have executives leading parties in the legislature does not mean those polities do not have the separation of powers in this key sense of distinct institutions tackling distinct political tasks.

\section{The separation of personnel}

Although some strategies within the separation of powers rubric do not prohibit the sharing of personnel, many of the advantages do require separation. This section describes two reasons for keeping the personnel separate between institutions, and for ensuring that one institution does not have discretionary control over the appointment, continuance and pay of the other institution's personnel (Hamiliton, et al., 1778/2008, pp. 256-257, 359); one is as a fetter to corruptness of character, the other is role-based virtues.

\section{Separate personnel as a fetter to corruptness of character}

A perennial reason to ensure that decisions are made by separate personnel is Lord Acton's shrewd observation that power corrupts, and (all the more) that absolute power corrupts absolutely. Anticipating Acton, Locke based his separation on the grounds that, 'it may be too great a temptation to human frailty, apt to grasp at power, for the same persons, who have the power of making laws, to have also in their hands the power to execute them...' (1690/1947, II:143).

In Montesquieu, this concern with the toxic relationship between power and virtue emerges in full (Singer, 2009, p. 99). The Frenchman (1748/1989) argued that, "it has eternally been observed that any man who has power is led to abuse it... So that one cannot abuse power, power must check power by the arrangement of things." (1748/1989, p. 155). Concerned above all with moderation, Montesquieu sometimes speaks as if any fetter on 
power, or overlap in jurisdiction, is desirable in itself. The more people's responsibilities overlap with others, and the more they must consider others' views, the more they become accustomed to moderating their will. In Montesquieu's view, the separation of personnel forges a fundamental change in the perspective, character and ambition of decision-makers.

As we will see below, the 'non-aligned interests theorem' observes that specific biases are unlikely to be shared by separate actors; thus, splitting decision-making among actors can result in a fairer outcome. The perennial need for an institutional actor (Ahmed) to coordinate his actions with other decision-makers impels him to give up self-serving projects (Hamiliton, et al., 1778/2008, p. 363). Over time and through force of habit, Ahmed alters his goals until he conceives only of plans other institutional actors will support. In so doing, as Montesquieu would put it, Ahmed moderates his will.

\section{Structural separation and role-based virtues}

Different institutions can develop their own professional practices and accompanying values-determining what it is, for example, to be a judicious judge or an effective executive. As Vile (1998, p. 17) observes: 'Differing procedures introduce differing values and different restraints; the emergence of an "institutional interest," the development of professionalism, the influence of colleagues and traditions, all provide the possibility, at least, of internal checks'.

The virtues each role requires may be distinct; the judge impartial; the executive decisive; and the legislator inclusive. The creation of distinct institutions allows each different population to develop a professional ethos specific to its task and method. Ideally, the constraints on these role holders-the limitations inherent to the specific institution in 
question - contribute to a way of being and living. This form of life as a professional practice provides its own internal reasons for performing one's role (Wueste, 2005, pp. 22-25); reasons that prohibit role holder's from 'toggling' their personas on and off at will (Wueste, 2013, p. 7). To mix metaphors, the swapping of hats as an agent shifts from one role to another is impossible if the ethos is dyed into the wool of the role holders' characters.

\section{Section summation: The separation of personnel}

The insights about character and role morality discussed above are mechanisms whereby, in Madison's words, the interest of the man becomes connected with the constitutional rights of his institution (Hamiliton, et al., 1778/2008, p. 257). But this only scratches the surface of the advantages of the separation of personnel. The following sections detail a host of mechanisms available in conjunction with the separation of personnel, including strategies of replacing decision-making, splitting decision-making, overlapping decision-making, balancing strengths and more.

\section{Replacing authority to avoid conflicts of interest}

Sometimes, an institution desires one result rather than another for purely self-interested reasons. In such cases, it makes sense to seek another institution with a more objective standpoint. Avoiding conflicts of interest (e.g by ensuring that an institution is not effectively a judge in its own case) is as important for institutions as it is for individuals.

The need to avoid conflicts of interest can force exceptions to the separation of powers. Sometimes, the executive itself needs to be policed, as in the case of the investigations into President Nixon's actions during the Watergate scandal (Vile, 1998, pp. 388-390). In another example, the legislative can deploy its lawmaking powers to redraw 
voting boundaries-entrenching the political power of the current majority through gerrymander. Himself no friend of executive prerogatives, Locke acknowledged that the direct conflict of interest in this case made the monarch better placed to render objective judgments on voting districts (Locke, 1690/1947,II: 157-158).

In these examples, direct conflicts of interest require exceptions to the separation of powers. In many cases, however, avoiding conflicts of interest impels the separation of powers-especially the independence of the judiciary. Some commentators distinguish between the judiciary and the executive on the basis of this independence. That is, far from beginning with a notion of what it is to be a judge and then crafting a separation of powers, the defining characteristic of judicial power lies in its institutional independence, its impartiality and its distance from the present government's political designs (Brown, 1992, p. 74). In the words of Lon Fuller (1955, p. 916), 'the social institution of adjudication loses its whole reason for being if we have no restriction against the bribing of judges'. As Brown (1992, p. 75) argues,

Judicial independence and the separation of powers ... form the cornerstone of the only power that the judiciary can really pretend to have - a theoretical ability to make objective, impartial, 'rational' decisions, free from the temporal and sectoral issues that dominate the lives of parliamentarians and public servants.

An especially dangerous breach of independence looms when the judiciary is allied with the prosecution. Here, the dissolution of separation between judge and administration creates a star chamber, where judge and prosecutor are the same person-a circumstance by no means relegated to ancient history (Brown, 1992, pp. 62-65). 
In these cases, the lynchpin question is not whether a type of activity is more or less judicial in nature, but rather whether the types of tasks required of the institutional agent are compatible-whether that agent is simultaneously called upon to offer objective and apolitical judgments while being a part of, or answerable to, the present administration (Brown, 1992, pp. 75-76).

\section{Splitting authority: Veto, assent and the 'coordination thesis'}

Many theorists justify the separation of powers through the 'coordination thesis' (as Magill terms it) (2000, p. 1185), which observes that certain abuses of power require plans involving executive, judicial and legislative elements. In these cases, the separation of powers stymies injustice because the three separate institutions would have to independently conspire (i.e. coordinate) in order to injure an individual. But, as Magill stresses, it is perplexing just how the coordination thesis is supposed to work. In fact, the coordination thesis can be challenged in two distinct ways. The first challenge questions whether the separated institutions actually possess the discretionary capability to thwart each other's self-interested designs. The second challenge questions whether such checking, even if it were possible, would actually occur.

Beginning with the first challenge, the coordination thesis assumes that each institution wields adequate discretionary scope to 'second guess' the operation of other powers, and so check their abuses of power. In response, however, Magill stresses, 'it is not the job of those exercising the executive or the judicial power to assess independently the wisdom of the congressional choice reflected in the statute' (2000, p. 1188). 
In reality, state institutions routinely check each other's designs. Perhaps the single most powerful way the government can injure a citizen is by arbitrary arrest and prosecution. The separation of powers between executive and judicial bodies curtails such persecution. An individual judge cannot himself physically arrest a citizen and gather evidence against her-nor can he create a law targeting that citizen. Equally, members of the executive can arrest the citizen, but cannot judge and punish her. State power can be wielded to injure particular persons only when the two bodies conspire in their persecution, for then the police can make a fabricated arrest, sure in the knowledge that the judge will sentence their victim. In this respect, the everyday activity of judges and juries constitutes the routine independent testing of the claims made by the executive agents of the police and prosecution.

Arbitrary arrest and prosecution becomes most dangerous when it is politically motivated; for example, when those in power subvert the democratic process through the arrest of opposition figures. For this strategy to succeed, the separation of powers between the legislative and the other two bodies requires coordination. If the reigning faction in the legislature wants to imprison members of the opposition, then they must conspire with both the executive and the judiciary to do so. Of course, the faction could accomplish the same feat by passing legislation directly targeting the opposition. However, even if such laws are within the legislature's constitutional powers, this method of persecution is far more visible than imprisoning opposition figures on trumped up charges. Ultimately, without conspiracy across the three institutions, the ordinary business of police and judicial activities prevents the three bodies succeeding in political persecution. 
Institutions also stymie injustice through more exceptional measures. Magill is correct that routine second guessing of legislation by the executive or judiciary does not occur. Even so, there are official avenues through which checks can be implemented in exceptional cases, such as an executive vetoing unjust legislation. And unofficial strategies abound. It is not hard to imagine local police being lax in officiating central government laws that discriminate against the nearby population, or judges deploying all the powers of interpretation at their disposal to minimize the injury exacted by an unjust law. Similarly, the army might refuse to perform acts it considers illegitimate. In the crisis that gripped Egypt in early 2011, the Egyptian army rejected orders from the Mubarak regime to fire on peaceful protestors. So too, the possibilities for whistle-blowing increase when multiple institutions must take part in controversial actions they have no stake in performing. In such cases, institutional actors struggle to keep their machinations 'in house'. In sum, even where each body avoids routinely second guessing the other's acts, institutional role holders can still thwart the self-interested or ideological designs of others. But will they do so? Here lies the second challenge to the coordination thesis. Even if separate institutions have the discretionary power to check the abuse of power by other institutions (through routine, exceptional or unauthorized methods), do we have any reason to believe they would do so? Indeed, isn't granting another agent discretionary or veto powers merely opening up a new opportunity for self-interested agents to abuse their powers? In the Federalist Papers, Hamilton (1778/2008, p. 109) showed a clear understanding of the risks of allowing veto power to trump a majority legislature decision, and the way this policy might: 'substitute the pleasure, caprice, or artifices of an insignificant, turbulent, or corrupt junto, to the regular deliberations and decisions of a respectable majority'. 
In answer to this second challenge, I adduce several reasons why a check by one institution on another might improve, rather than diminish, institutional integrity: the exceptional nature of the veto; three theorems ('one good apple'; non-aligned interests; and aligned legitimate interests); and the limited power of the veto. These five reasons are discussed below.

\section{The exceptional nature of the veto}

The vetoing institution might be more impartial on a matter if its discretionary power attracts attention. For example, in the context of the Federalist Papers' arguments on the US Constitution, the exceptional nature of the proposed Presidential veto on legislation allayed concerns over its abuse. Aware that the King of England held such a power and refrained from wielding it (in the eighteenth century, at least), Hamilton emphasized that the US President's recourse to the veto would be exceptional at best (1778/2008, p. 361). By reason of this public, exceptional and hence controversial nature of the veto, the executive would struggle to conceal its true motives, as compared with the legislature's routine crafting and ratifying of policies or bills.

\section{The 'one good apple' theorem}

Multiplying the institutions involved in decision-making increases the chance that at least one of the institutions will act in good faith. If so, that institution will resist the unjust impositions attempted by other bodies. The separation of powers is built around a cleareyed awareness that people in power can be corrupt or at least corruptible-rather than on the dogma that corruption is inevitable for every single member of every single institution. 
One potential 'good apple' is the citizen population itself. With some caveats, the citizenry en masse is usually the group standing to gain most from a government body's institutional integrity. As we will see below with respect to Machiavelli and Montesquieu, granting the general public a partial authority in a variety of domains exploits the broad alignment of their interests with the public interest (as the name implies).

\section{The non-aligned interests theorem}

'It is far less probable,' Hamilton (1778/2008, p. 361) observed, 'that culpable views of any kind should infect all the parts of the government at the same moment and in relation to the same object, than that they should by turns govern and mislead every one of them'. I will call this the non-aligned interests theorem. This theorem states that self-interested agendas are unlikely to be shared across a range of different actors housed at different institutions. Hence, if a multitude of actors possess discretion over executing a policy (e.g. an executive veto or bicameral consent to a bill), their conflicting interests will clash, and neither will succeed in subverting the public interest for their own gain.

To say that two institutions, $A$ and $B$, do not hold the same self-interested objective does not mean one of them acts impartially. To the contrary, both A and B might wish to enrich one group and persecute another. However, so long as each body has different ideas about who it wishes to target, each may hamper the other in its designs. Judges and police, for example, may have little reason to faithfully implement laws privileging the faction in control of the legislature. They may neuter such laws not for moral reasons (as per the 'good apple' theorem), but simply because they do not share the faction's self-interested designs furthered by those laws. As a result, A and B each stymie the self-interested designs of the other, though neither of them do so out of a concern for the public good. Ideally, the 
prospect of such resistance nips abuses in the bud: 'When men, engaged in unjustifiable pursuits, are aware that obstructions may come from a quarter which they cannot control, they will often be restrained by the bare apprehension of opposition, from doing what they would with eagerness rush into, if no such external impediments were to be feared' (Hamiliton, et al., 1778/2008, p. 363).

The non-aligned interests theorem explains how two self-interested institutions can impede each other's self-serving activities. But does this leave both institutions free to positively perform their justified role? Perhaps not-for each institution can selfishly block even the justified and necessary actions of the other body. As Hamilton (1778/2008, p. 109) acknowledged, a self-interested 'negative' permits the measures of government to be 'injuriously suspended, or fatally defeated'. Does the creation of the veto therefore merely swap one evil (self-interested policy-making) for another (self-interested obstruction of legitimate policy)?

We will see in a moment how self-interested agents might prefer to perform their role appropriately, rather than not perform it at all. But political theorists have pondered a different response to the problem of self-interested obstruction-namely, a bad, corrupted or abuse-facilitating law might prove worse than no law at all (Hamilton, et al., 1778/2008, p. 361 ; Vile, 1998, p. 116). If so, then the benefits of preventing bad new laws will dwarf the costs of obstructing good ones. The classical liberal suspicion of coercive power supports this view. Increasing the hurdles to the imposition of new legislation ensures that the only laws enacted are ones acceptable to a wide array of institutional perspectives. All political power over a citizen (Amy) not used in a legitimate way for legitimate purposes violates Amy's liberty by deploying coercive power over her in a way, and to a purpose, to which she 
has not consented. Madison welds the separation of powers to liberal consent thus: 'The Rulers who are guilty of such an encroachment, exceed the commission from which they derive their authority, and are Tyrants. The People who submit to it are governed by laws made neither by themselves, nor by an authority derived from them, and are slaves' (Brown, 1992, p. 68). On this footing, unjust law (coercively imposing illegitimate duties) menaces civilian freedom more than the biased obstruction of a worthwhile new law (coercively imposing no new duties). From the standpoint of classical liberalism, the constitutional structure must protect the integrity of the legislature when it acts-the integrity of the legislature when it is gridlocked does not herald the same threat to human freedom. $^{3}$

\section{The aligned legitimate interests theorem}

Even when institutional agents are purely self-interested, each agent will have at least has some interest in doing the job she is supposed to do. By effectively performing her role, she increases the legitimacy (and hence on-going power) of the institution, and cements her own authority within the institution. Also, as a member herself of the general citizenry, the institutional agent benefits from the existence of social peace and liberty created by a functioning legislature, executive and judiciary. As such, if all the self-interested, biased ways of performing her role are vetoed by checking powers (in line with the non-aligned interests theorem), then the agent is left only with her remaining non-partisan interest, which is to enhance her status and the status of her institution by performing her role well.

\footnotetext{
${ }^{3}$ This claim depends, of course, on exactly what types of acts might be gridlocked. Although the passage of new laws might not, strictly speaking, be vital, at least some legislative acts are necessary to the functioning of modern government. In this respect, the separation of powers is forever attempting to navigate between the Scylla of governmental abuse and the Charybdis of governmental gridlock.
} 
This is, I think, what Montesquieu $(1748 / 1989$, p. 164) hinted at when he says of the two bicameral houses and the executive that, 'the form of these three powers should be rest or inaction. But as they are constrained to move by the necessary motion of things, they will be forced to move in concert.' In other words, the vetoing powers of each institution create a natural state of rest-unless they all acquiesce, inaction results. But complete inaction benefits neither the institution nor its members. From their perspective it is better to have impartial legislation than no legislation. If one cannot do one's job corruptly, the task may as well be done effectively than not at all. This positive impetus to act drives Montesquieu's 'necessary motion'.

We can observe these ideas at work in Locke's explanation of why an executive who is also legislator poses particular threats to integrity. One part of Locke's account of why the legislature can be trusted to make appropriate laws is that all members of the legislature will eventually be subject to the laws they make. This gives them a motivation to make fair laws. But if the legislators also have control over the enforcement of the laws (because they control the executive power), then this motivation is dissolved. The legislature can make laws without a care for what it might be like to have themselves or their nearest and dearest in breach of the law (Locke, 1690/1947, II:143; Zuckert, 2012, p. 361). A lack of integrity in one institution (executive enforcement of the law) thereby facilitates a lack of integrity in another (legislative creation of the law). Although there are always possibilities for abuse in the operation of each power on its own, some combinations of powers in the same person allow new types of corruption and abuse. If one person's capacity for corruption is narrowed to one dimension of decision-making, this may make her pursuit of narrow self- 
interest more difficult than when she can manipulate several dimensions of the political process at once.

\section{The limited power of the veto}

A classic way to use one institution to check another is to give it a power of vetosometimes without also giving it the power to initiate action, policy or legislation. This more limited power (negative rather than positive) can be a benefit in terms of integrity. ${ }^{4}$ Arguably, the authority to use a self-interested veto is not as liable to abuse as the authority to employ a self-interested capacity for creation. One will always possess a self-interested reason to create a particular new law, but one can only occasionally find a self-interested reason to block a universally applicable law. If that is right, then self-interest rears its head less often with the veto than with initiation and proposal.

\section{Section summation: Checks and balances}

In the various ways outlined above, integrity and improved decision-making can be increased by splitting authority for an action, law or decision across several institutions. This separation does not make the institutions isolated, in the sense that there is no interaction between them. Instead, the qualified independence of each body is created precisely to make possible desired interactions. For example, to have one institution performing a check (such as a vetoing power) on another, it is necessary to first have that institution substantially separated from the other. Similarly, to keep institutions separate from each

\footnotetext{
${ }^{4}$ Additional reasons bulwark this limitation. An agent that can veto policy in exceptional cases may not be well-placed for initiating policy. For example, the executive is poorly placed to perform the difficult and timeconsuming task of formulating legislation, which usually requires substantial legal expertise, lengthy deliberation with stakeholders, weighing of consequences and responses, and so on.
} 
other, it is often necessary for an institution to have enough control over others to sustain the institution's ability to repel incursions into its areas of jurisdiction. This was the justification for the Presidential veto of legislation in the US system (Hamiliton, et al., 1778/2008, pp. 245,360$)$.

Ultimately, for each such institutional check, the key questions are: What provides Institution A with the effective capacity to check Institution B? What provides Institution A with the effective motivation to check Institution B? And-the master question-what prevents the answers to these first two questions constituting reasons that motivate and empower Institution A to wrongfully exploit its capacity to check Institution B? Three theorems-one good apple, non-aligned interests and the aligned legitimate interestsprovide potential answers to the master question, but the creation of workable checks and balances remains a challenging task, as the history of various constitutional checks implies (Kirwan, 1995). Indeed, Montesquieu's explanations of systems with workable checks and balances are very much historical ones, rife with contingencies and unintended consequences. They are social ecologies that display a healthy tendency towards equilibrium; such systems are not always easy to create. To the contrary, Montesquieu (1748/1989, p. 63) argued that, despite men's love of liberty and hatred of violence, all forms of moderate government were forever battling to avoid collapse into their default position of despotism.

\section{Balance of strengths}

One way of ensuring limitations on an institution is to juxtapose it with another institution that can balance the first institution's power. The idea here is to have rival institutions that 
each stand to lose power when the other gains it. The 'balance of powers' (strengths) juxtaposes institutions in a tussle for control.

This balance is sometimes characterized as using the separation of powers to inject tension and competition (even jealousy and envy (L. Little, 2000)) within the ranks of government, so as to keep the government distracted internally and thus less capable of tyrannizing the citizenry (Magill, 2000). An analogy might be drawn here to the balance of powers between nations, where a rough equality of military strength serves to keep a larger peace, because no single nation possesses enough power to make it confident in waging war against the others. Each nation may have an altogether belligerent will, but the rough equality in strength creates peace. Without question, there are elements of such an opposition in the use of checks and balances, and critics throughout history have highlighted the conflict and disunity these mechanisms assume and foreground (Vile, 1998, p. 203). Indeed, in some cases, institutional checks to others' powers can seem so severe as to hint at the precariously balanced equilibrium created by the threat of mutually assured destruction; examples of such checks include executive prorogation and dissolution of the legislature, and legislative impeachment of the executive.

However, using the separation of powers to inject tension and competition is not the only way of understanding the balance of strengths as an institutional integrity measure. Another way, and the most important, is through defensive strengths. The aim is one of institutional stability, so that each institution keeps to its own tasks using its own capacities, and is unable to usurp the activities of the other. This result is achieved when each institution has strong motivations and capacities to prevent incursions by other institutions into its purview, while simultaneously having few available resources that would enable it to 
invade the domain of others. Drawing one of the distinctions that can be made between the motives of jealousy and envy, the ideal is to have each institution jealous of its own existing capacities and fearful of rival institutions impinging on those, while at the same time not being envious of the existing capacities and strengths of others. As such, what is not required is any sort of broad equality of strength among the different institutions, nor any sort of ongoing tensions within their everyday institutional business. Rather, tension and the marshalling of strength only develop when one institution intrudes upon another's activities. As such, the challenge in setting up a beneficial balance of powers involves ensuring each institution jealously guards against over-reach by its rival, without its will for institutional power encouraging its own over-reach.

The idea of 'balance' here implies the continuance of the prescribed status quo. Balance occurs when each institution's raw power is sufficient to enable it to defend itself against usurpation by a rival. It refers to a distribution of defensive strength ensuring that the division of authorities, tasks, checks and balances as laid down in the constitutional structure is sustained over time. It is in this sense that a balance of strengths can be seen as a necessary condition for sustaining the separation of powers-as the early history of America demonstrated (Vile, 1998, pp. 160-167). As Madison put it (Hamiliton, et al., 1778/2008, p. 245),

It will not be denied, that power is of an encroaching nature, and that it ought to be effectually restrained from passing the limits assigned to it. After discriminating, therefore, in theory, the several classes of power, as they may in their nature be legislative, executive, or judiciary, the next and most difficult task is to provide some practical security for each, against the invasion of the others. 
One avenue to promote this goal of a balance of defensive strengths is to develop a specific role morality, as has been done for the judiciary, that emphasizes self-awareness and a positive conception of the importance of one's function and capacities, while limiting envy of others' roles in the political system (L. Little, 2000, pp. 92-93).

There are other options. Pogge lists a number of ways in which defensive strength can impel a retreat by an institution that was hitherto pushing its powers to the brink of its legitimacy. Drawing on examples from cases and constitutional crises in the US, Pogge describes how authorities might retreat:

...impelled perhaps by what Habermas has aptly dubbed the forceless force of the better argument, by moral suasion, by widespread condemnation, by the desire to avert a crisis for the benefit of the whole society, or by a sober calculation that it would lose if the dispute were to be decided by force of arms. (2009, p. 205)

Some of these methods were anticipated by Montesquieu. This is especially true of the 'widespread condemnation' mechanism, whereby the invaded institution publicises the other's power grab and appeals to public pressures to restrain its rival. To the institutions in question, their turf wars and factional disputes may be zero-sum games; however, to the public, these interactions are socially beneficial insofar as they sustain a larger stability in which each institution plays its own role. Without any need for dedicated integrity agencies, the rivalry between the two institutions creates a natural fetter to their ambitions, because each is motivated to publicise the other's over-reach, and can expect public opinion and resourcing to mobilize against its competitor. Envisaging a case where two factions each side with one power of government (legislative or executive), Montesquieu (1748/1989, p. 327) says of the English system, 'As these parties are made up of freemen, if one party 
gained too much, the effect of liberty would be to lower it while the citizens come and raise up the other party like hands rescuing a body'. Rather than the status quo being provided by the intrinsic balance between the two opposing factions, the balance of power is secured by the strategic support offered by a third party with a vested interest in the status quo: the citizenry at large. Political theorist Lee Ward (2007, p. 559) sums up Montesquieu's understanding of the English system: 'Ultimately it is the self-interested passions of the people that give the institutional checks on power their vitality'. Ever jealous to potential infractions of their liberty, the general public (who are, after all, the major beneficiaries of a polity's institutional integrity) rally to the cause of the vulnerable institution, protecting it from the other's expansion.

Richard Little (2007, pp. 11-12) helpfully distinguishes two conceptions of the balance of powers. On the one hand, there is the adversarial balance of power, where antagonistic forces aim to manipulate the overall distribution of strength in a system to their own advantage. This maps onto Magill and Laura Little's conceptualization of envy and conflict between institutions, where there is unremitting antagonism between the opposed groups. The second conception is of an associational balance of power, where the institutions acknowledge their collective responsibility to maintain order and so aim to create a stable equilibrium of power. This latter characterization resonates with the 'defensive strengths' account described above, in which each institution has an interest in the effective functioning of the others, provided they do not overstep their institutional remit.

Is there, then, any room within a well-governed polity for the adversarial balance of power? Perhaps. Montesquieu's account of the English separation of powers in 1748 
(described above) resembles Machiavelli's sixteenth century analysis of the classical Roman republic, where an adversarial balance of powers loomed large (Rahe, 2011; Sullivan, 2006). Machiavelli saw the public's fundamental political sentiment as a desire not to be dominated (1961/1514, p. 67). He contrasted this sentiment to that of the nobles, whose central desire he saw as being precisely to oppress the public. In Machiavelli's view, the Roman plebs rightly feared and despised the nobility. Machiavelli recounted a host of ways in which the people vigorously employed their raw strength to influence and refigure the governing political institutions, including how they publically demonstrated, withheld military service and even evacuated the city (McCormick, 2001, p. 301).

Both Machiavelli's Roman citizens and Montesquieu's English have a desire for libertyand these sentiments are for both writers pivotal components of the governance systems they describe. Certainly, to a modern eye, Machiavelli went too far in his enthusiasm for the tumultuous relationship between the Roman people and the nobles. He recommended several measures, such as the public's powers of 'accusation' and their need to 'vent' their emotions, which patrolled the elites only by fomenting the terrors of mob rule. Montesquieu rejected Machiavelli's ferocious populism as one-sided, preferring the English system where the citizen's security is protected from all sides (and not only against the nobles). Yet Montesquieu nevertheless appreciates Machiavelli's basic insight: liberty can be protected because, and not in spite of, discord within the polity (Rahe, 2011; Sullivan, 2006). As the Frenchman says,

That which is called union in a Body Politic is a thing quite equivocal; the true union is a union of harmony which causes all the parts, however opposed they may seem to us, to concur in the general good of the Society, as dissonances in Music concur in an 
overall accord. It is possible for there to be union in a State where one believes that one sees only turmoil, which is to say a harmony whence comes the happiness that is alone genuine peace. (Rahe, 2011, p. 130)

The turmoil of Montesquieu's opposed parts suggests Little's adversarial balance of powers, where 'balance' implies not a placid equilibrium (McCormick, 2001, p. 301), but rather a vigorous opposition between two or more parts of a political system-an opposition, however, that keeps the system's volatility within certain bounds. The volatility fuels invigilation and even drastic actions from each side against its rival, but such actions do not threaten the existence or security of the parts of the system as such. Applied to the modern era, it is at least possible, as McCormick (2001, pp. 310-311) urges, that Machiavelli is right that a fierce public antagonism towards elites, combined with the institutional capacity to exert opposition when necessary, is a sine qua non of greater governmental accountability. If so, then this adversarial balance of power (i.e. this opposition of strengths that constrains conflict within certain limits) may prove a useful measure within a larger integrity system.

\section{Vertical accountability}

Vertical accountability-where the governed use democratic elections to replace the governors-remains one of the more successful integrity measures. Although the people are themselves subject to the laws of the legislature and the actions of the executive, their power of suffrage allows them to respond to breaches of integrity by those institutions. It is the people at large, after all, who have the most to gain from their institutions performing their publically stated roles-it is the public's interest that most closely aligns with institutional integrity. As we have seen, this insight arises in vivid form in Machiavelli, who 
foregrounded the institutions of the public over the nobility in his early invocation of the separation of powers, because he held that the former was of higher integrity. Machiavelli believed that, since the intrinsic motivation of the nobility was always to oppress the people, elites could not be trusted with managing the affairs of state without vigorous oversight by the people (McCormick, 2001). Contrariwise, he saw the people's fundamental motivation as simply to avoid being oppressed. Viewed from the position of the security and integrity of the state, this motivation was more honest, feasible and public spirited. Machiavelli does accept that the public has its own weaknesses, but even here he suggests that, as McCormick explains, 'the people have a sense of their own limitations and their need for the governing expertise of their class antagonists' (2001, p. 307). While there is thus an irremovable role for elites in governing the republic, the public are the best judges of the nature and extent of this role.

This is not to say that democracy rises to the pitch of a perfect governance strategy (Pope, 2000, pp. 24-26)-a point of which Machiavelli was well aware (McCormick, 2001). Still, if it is not viewed as a panacea for integrity concerns, vertical accountability plays a role alongside other measures. As Madison (Hamiliton, et al., 1778/2008, p. 257) says, 'A dependence on the people is, no doubt, the primary control on the government; but experience has taught mankind the necessity of auxiliary precautions'.

The involvement of the general public through voting is the most obvious instance of vertical accountability-but it is not the only way in which their sheer strength can manifest. The population can take to the streets, protest, riot, blockade, devote monetary resources, strike, publicise and engage in conscientious objection. In these ways they can apply social and other pressure to state actors: police, army, politicians, public servants and judges. As 
we saw, it was these shifts in strength, as much as authorized voting power, that allowed the English citizenry to play their role in Montesquieu's separation of powers, by rallying to the cause of any public institution perceived to be under assault. Indeed, Locke's 'right of revolution'-where, in desperate situations, the populace have a right to rise up en masse against despotic leaders - takes its place within his discussion of institutional checks and separation of powers (Locke, 1690/1947, II:149). As Pogge (2009, p. 204) observes, it is a complex empirical question whether such a right diminishes the rule of law by encouraging citizens to transgress the law, or works in precisely the opposite fashion by encouraging the authorities to govern within the rule of law.

\section{The overlapping of jurisdiction: federal and local governments}

Montesquieu was famously impressed by the tripartite horizontal division of powers in the constitution of England between executive, legislative and judiciary, but he also (though less famously) warned of a vulnerability in the political arrangements of both France and England: namely, their centralization of power. Montesquieu saw this centralization of power as expunging the regional power held by lords in the feudal period (2007, pp. 565570). Although the lords only held a subordinate power, their strength nevertheless mediated and tempered the monarch's edicts. Power was shared among regions and the sovereign, and 'produced rule with an inclination to anarchy and anarchy with a tendency to order and harmony' (Montesquieu, 1748/1989, p. 619).

Arguably, modern federal, state and local council institutions serve the same purpose (L. Little, 2000, pp. 97-98; Vile, 1998, p. 188). Overlapping and intertwining responsibilities and jurisdictions may have their inefficiencies, but they also make it more difficult for any single institution to make nakedly self-interested decisions without being 
confronted by the attention and resistance of rival actors. The need for coordinated action, and for obtaining consent across multiple institutions, increases the public space for negotiation and decision-making. So too, the coordination thesis described above can apply to these federalist institutions when their areas of jurisdiction overlap. In his discussion of the separation of powers in the proposed federal constitution, Madison emphasized that the rights of the people would benefit from a 'double security' (Hamiliton, et al., 1778/2008, p. 258). 'In the compound republic of America,' Madison explained, 'the power surrendered by the people is first divided between two distinct governments, and then the portion allotted to each subdivided among distinct and separate departments'.

\section{Representativeness and informed decisions: the question of social diversity}

Having separate institutions with separate personnel offers the possibility of increased representativeness across the affected population in situations where the institutions must interact to create an outcome. If different groups in society-distinct socioeconomic classes, minorities, generations, geographical groups and so on-predominate in a particular institution, then decision-making or action across institutions offers the potential for increased inclusivity and for less one-sided decision-making. In principle at least, the 'mixed regime' of monarch, aristocracy and commoners aimed to benefit from this sort of pluralism, intermingling the different institutions to form a larger political whole in which each group had a voice. Equally, some held that the system balanced the tax consumers of the monarchy and the tax payers of the commons (Vile, 1998, p. 189). In a similar fashion, the conservative and historical nature of judicial decision-making can allow the generation of the past to check the generation of the present (L. Little, 2000, p. 57). 
In the increasingly classless societies of the modern era, this type of class-based institutional diversity is of course less attractive. Even so, the insight still finds a place in modern democracies with bicameral legislatures. Here, two houses of parliament, each populated through different methods of election and selection, interact to craft legislation acceptable to both houses (Montesquieu, 1748/1989, p. 160). Similarly, federalist arrangements can foster a diversity of inputs into policy formulation and implementation. Decisions that have implications for one region can be informed by institutions local to that region, allowing local representatives to have a voice on federal decisions affecting them. 'Community participation clauses' often appear in local government acts, allowing municipal voices a more direct mode of participation in governmental decisions, especially if the local government has a degree of autonomy from state or federal powers (Grant \& Dollery, 2012). The same method has been recommended for the administrative branch of government. Rather than gaining legitimacy through transmission of authority from the elected legislature or executive (both of which lie at a considerable distance from administrative decision-making), some separation of powers theorists have argued that administrative discretion can achieve democratic legitimacy by engaging directly with stakeholders in its decisions (Carolan, 2009).

This representativeness has consequences for institutional integrity. Increased responsiveness to stakeholders and diverse social groups means that more parts of the society have access to the decision-making process, which helps them to monitor what is happening and how decisions are made. Further, because they have input into the process, there is less likelihood of the subsequent policies meeting resistance on the ground and over time. The policies can therefore be more realistic, because they include not merely 
political elites, but those whom the policy is intended to benefit, or those who will suffer its restrictions.

\section{Two remaining inter-relations}

Before concluding, there are two remaining inter-relations among institutions worth noting: the non-separation of personnel and sheer messiness.

\section{The non-separation of personnel}

The makeup of the personnel of a particular institution is always a key factor in consideration of its capacity to play a role in an integrity system. Although the separateness of personnel can often be a virtue, the reverse is sometimes true. An example already noted is Locke's legislators, who are taken from the general population, and must subsequently return to it, in order to ensure the fairness of the laws they pass. Similarly Montesquieu (1748/1989, p. 165) and Machiavelli $(1961 / 1514$, p. 85$)$ urged that the armies of a republic be drawn from the people and share their values, to prevent the military force becoming a source of oppression.

Locke too gives reasons why it is sensible to have one actor-the executiveresponsible for the two distinct tasks of enforcing domestic rule of law and dealing with foreign affairs (Locke's 'federative' power). Because the same type of capacities and processes are involved in each of these tasks, it makes sense to assign the two distinct tasks to a single institutional agent (Locke, 1690/1947, II: 146-148).) 
A further example is jurying by the people. Montesquieu reflects that this practice makes it easier for people to fear the law, rather than fearing particular persons or even groups of persons:

the power of judging, so terrible among men, being attached neither to a certain state nor a certain profession, becomes, so to speak, invisible and null. Judges are not continually in view; one fears the magistracy, not the magistrates. $(1748 / 1989$, p. 158)

\section{Sheer messiness}

The complexity of the myriad inter-relations and governance strategies sketched above has hopefully buried any notions of the simplistic tripartite separation of powers. Indeed, it is arguable that messiness-in the sense of a complex and unsystematic tangle of checks and balances, divisions and overlaps-can itself be a virtue for an integrity system. The skeins of overlapping responsibilities, fickle public attention, unclear jurisdictions, murky rivalries, shifting memberships and so on can create an ethical mélange where corrupt agents cannot be confident their abuses will go undetected and unpunished. They cannot be certain who they need to hide their actions from, and who they must fool, bribe or threaten. If Machiavelli was right that few are corrupted by few, it might in an analogous spirit be posited that simple regimes can be corrupted simply.

We can see this quality of informal messiness in the metaphors used to capture integrity systems. Wueste (2005, p. 22) draws on Allen's idea of webs of accountability; Sampford, Smith and Brown (2005, pp. 105-107) advocate the image of a functional but complexly interwoven bird's nest; and Buchanan and Keohane (2006, p. 432) advance an 
ecological conception of legitimacy in emphasizing the significance of the broader institutional environment.

\section{Conclusion: We separate only to reconnect}

If it is important to separate powers, then why scramble their areas of competence, allowing one to intrude into the basic workings of the other? Critics of the simplistic tripartite separation of powers complain that the separation effectively contains two conflicting mechanisms: the strategy of separation and the strategy of reconnection.

In response, we separate only to reconnect. It is precisely because of the manner in which the institutions are made distinct from one another-with different personnel, interests, procedures and powers-that those institutions are fit for reconnection. It has long been known that political power needs to be checked and balanced. But there is an obvious difficulty in giving a single institution (much less a single person) the role of checking and balancing itself. This need for accountability came first, and the elements that were necessary to achieve such accountability were designed afterwards. The separation of sovereign rule into legislature, executive and judiciary allowed checking to occur through the forging of new inter-relationships among those institutions.

I have argued that we should think of the separation of powers as a rubric encompassing several distinct governance strategies. These strategies direct attention to the inter-relations between institutions-highlighting the contribution these inter-relations make to securing institutional integrity. If that is right, the myriad strategies of Locke and Montesquieu, and of Machiavelli, Kant and Madison, remain a fertile source of insight for those aiming to improve integrity outcomes. 


\section{References}

Brown, A. J. (1992). The wig or the sword? Separation of powers and the plight of the Australian judge. Federal Law Review, 21, 48-89.

Buchanan, A., \& Keohane, R. O. (2006). The Legitimacy of Global Governance Institutions. Ethics and International Affairs, 20(4), 405-437.

Carolan, E. (2009). The New Separation of Powers: A Theory for the Modern State. Oxford: Oxford University Press.

Formosa, P. (2014). The Ends of Politics: Kant on Sovereignty, Civil Disobedience, and Cosmopolitanism. In P. Formosa, A. Goldman \& T. Patrone (Eds.), Politics and Teleology in Kant (pp. 37-58). Cardiff: University of Wales Press.

Fuller, L. (1955). The Philosophy of Codes of Ethics. Electrical Engineering, 74, 916-917.

Grant, B., \& Dollery, B. (2012). Autonomy versus Oversight in Local Government Reform: The Implications of 'Home Rule' for Australian Local Government. Australian Journal of Political Science, 47(3), 399-412.

Hamiliton, A., Madison, J., \& Jay, J. (1778/2008). The Federalist Papers. Oxford: Oxford University Press.

Jefferson, T. (1993). The Political Writings of Thomas Jefferson. Chapel Hill: The Thomas Jefferson Foundation.

Kant, I. (1797/1996). The Metaphysic of Morals. New York: Cambridge University Press. 
Kirwan, K. A. (1995). The Use and Abuse of Power: The Supreme Court and Separation of Powers. Annals of the American Academy of Political and Social Science, 537, 76-84.

Little, L. (2000). Envy and Jealousy: A Study of Separation of Powers and Judicial Review. Hastings Law Journal, 47, 47-121.

Little, R. (2007). The Balance of Power in International Relations. New York: Cambridge University Press.

Locke, J. (1690/1947). Two Treatises of Government. New York: Hafner.

Machiavelli, N. (1961/1514). The Prince (G. Bull, Trans.). Harmondsworth: Penguin.

Magill, E. (2000). The Real Separation in Separation of Powers Law. Virginia Law Review, 86(6), 1127-1198.

McCormick, J. P. (2001). Machiavellian Democracy: Controlling Elites with Ferocious Populism. American Political Science Review, 95(2), 297-313.

Montesquieu. (1748/1989). The Spirit of the Laws. New York: Cambridge University Press.

Pogge, T. (2009). Kant's Vision of a Just World Order. In T. Hill (Ed.), The Blackwell Guide to Kant's Ethics (pp. 196-208). Oxford: Wiley-Blackwell.

Pope, J. (2000). Confronting corruption: The elements of a National Integrity System ('The Transparency International Source Book'). Berlin: Transparency International.

Rahe, P. A. (2011). Montesquieu's anti-Machiavellian Machiavellianism. History of European Ideas, 37, 128-136. 
Sampford, C., Smith, R., \& Brown, A. J. (2005). From Greek Temple to Bird's Nest: Towards A Theory of Coherence and Mutual Accountability for National Integrity Systems. Australian Journal of Public Administration, 64(2), 96-108.

Singer, B. C. J. (2009). Montesquieu on Power: Beyond checks and balances. In R. E. Kingston (Ed.), Montesquieu and his legacy (pp. 97-112). Albany: SUNY Press.

Sullivan, V. B. (2006). Against the despotism of a republic: Montesquieu's correction of Machiavelli in the name of the security of the individual. History of Political Thought, $27(2), 263-289$.

Vile, M. J. C. (1998). Constitutionalism and the Separation of Powers (2nd Edition ed.). Indianapolis: Liberty Fund.

Ward, L. (2005). Locke on Executive Power and Liberal Constitutionalism. Canadian Journal of Political Science, 38(3), 719-744.

Ward, L. (2007). Montesquieu on Federalism and Anglo-Gothic Constitutionalism. Publius, $37(4), 551-577$.

Wueste, D. E. (2005). We need to talk... about institutional integrity. New York: RIT Press.

Wueste, D. E. (2013). Trust me, l'm a professional: Exploring the conditions and implications of trust for the professions. Research in Ethical Issues in Organizations, 9, 1-12.

Zuckert, M. (2012). On the Separation of Powers: Liberal and Progressive Constitutionalism. Social Philosophy and Policy, 29(2), 335-364. 